\title{
"Minimum Input, Maximum Output, Indeed!" Teaching Collocations Through Collocation Dictionary Skills Development
}

Sugene Kim, Department of English Studies, Nagoya University of Commerce $\mathcal{E}$ Business, Nisshin, Japan (sugene_kim@nucba.ac.jp)

\begin{abstract}
This study examined the teachability of collocations through cultivating EFL learners' collocation dictionary skills. Fifty-nine EFL college students participated in the study, and they received two 75-minute instructions between pre- and post-tests: one on the definition of collocation and its importance, and the other on the skill of looking up collocational information in the Naver Dictionary - an English-Korean online dictionary. During the second instruction, the students were trained to consult the dictionary for collocation production in the order of node word selection, word sense distinction, collocate type location, and feasible collocate identification. A comparison of collocation production test scores through a paired-samples $t$-test indicated that teaching collocation dictionary skills substantially improves learners' ability to produce natural collocations regardless of proficiency differences. In addition, the survey data collected at the end of the semester suggested that the participants perceive the instruction as necessary and helpful in gaining collocational competence and that their dictionary consultation behaviors have changed after receiving the instruction. Equipping EFL learners with collocation dictionary skills was also found to help them raise a sense of learner autonomy.
\end{abstract}

Keywords: COLLOCATION, COLLOCATION DICTIONARY, DICTIONARY SKILLS, EFL WRITING, L2 WRITING, COLLOCATION ERRORS, L1 INTERFERENCE, COLLOCATIONAL COMPETENCE, LEARNER AUTONOMY

Opsomming: "Sowaar minimum inset, maksimum uitset!" Die onderrig van kollokasies deur woordeboekvaardigheidsontwikkeling ten opsigte van kollokasies. Hierdie studie het die moontlikheid ondersoek om kollokasies te onderrig deur EVTleerders se woordeboekvaardighede te ontwikkel ten opsigte van kollokasies. Nege-en-vyftig EVTkollegestudente het aan die studie deelgeneem. Hulle het twee opleidingsessies van 75 minute elk tussen die aanvanklike en uiteindelike toetse ontvang: een oor die definisie van die kollokasie en sy belangrikheid, en die ander oor die vaardigheid om kollokasionele inligting in die Naver Woordeboek - 'n Engels-Koreaanse aanlyn woordeboek - op te soek. Tydens die tweede opleidingsessie is die studente opgelei om die woordeboek te raadpleeg vir die produksie van kollokasies in die volgorde van noduswoordseleksie, betekenisonderskeiding, die opsoek van kollokasiesoorte, en die identifisering van werkbare kollokasies. 'n Vergelyking van die resultate vir kollokasieproduk- 
sie deur 'n $t$-toets vir gepaarde steekproewe het getoon dat die onderrig van woordeboekvaardighede ten opsigte van kollokasies die leerders se vermoë om natuurlike kollokasies te produseer aansienlik verbeter het ondanks vaardigheidsverskille. Daarbenewens het die ondersoekdata wat aan die einde van die semester ingesamel is, daarop gedui dat die deelnemers die opleiding as noodsaaklik en nuttig beskou het om kollokasionele bevoegdheid te verwerf en dat hulle manier om woordeboeke te raadpleeg ná die opleiding verander het. Daar is bevind dat die toerus van EVT-leerders met woordeboekvaardighede ten opsigte van kollokasies help om 'n gevoel van selfstandigheid by leerders te wek.

Sleutelwoorde: KOLLOKASIE, KOLLOKASIEWOORDEBOEK, WOORDEBOEKVAARDIGHEDE, EVT-SKRYFWERK, L2-SKRYFWERK, KOLLOKASIEFOUTE, L1-INTERFERENSIE, KOLLOKASIONELE BEVOEGDHEID, SELFSTANDIGHEID BY LEERDERS

\section{Introduction}

Ever since studies in the 1980s demonstrated convincingly that collocations play an important role in characterizing overall language proficiency (Kennedy 1990, Sinclair 1991, Granger 1998), the importance of collocations has been at the center of attention among both English as a second language (ESL) and a foreign language (EFL) researchers (Wray 2002, Nesselhauf 2005). Amid burgeoning empirical evidence suggesting positive effects of teaching collocations, both ESL and EFL researchers agree that collocations need to be taught systematically (Nattinger and DeCaricco 1992, Martyńska 2004).

To date, studies have been mainly interested in finding answers to "which collocations to teach based on what technique at which learning stages" (Cowie 1998, Granger and Meunier 2008). For example, a web-based project commonly referred to as "collocator" (Wible et al. 2006) intended to help both learners and teachers know which collocations to attend to by highlighting the collocations from a page being viewed. In the study of Ackermann and Chen (2013), they came up with the academic collocation list with 2,468 entries compiled from the Pearson International Corpus of Academic English. Regarding how to teach collocations, the pedagogical experiments have suggested a few methods such as awareness-raising and attention-drawing. Both approaches consist of strategies aimed at bringing collocations to the learners' attention, with an expectation that learners who become aware of collocations will use them more beneficially. These approaches have been tried extensively in various contexts, confirming that learners with raised consciousness on collocations are indeed better at using them correctly (Jiang 2009, Ying and O'Neill 2009).

For learners studying English for academic purposes, it has been proved that teaching collocations from reading - specifically through consciousness raising - can raise their competence in academic interactions (Conzett 2000, Lewis 2000). However, teaching certain collocational expressions through raising consciousness alone is not sufficient enough when it comes to fostering learner autonomy. In reality, English learners encounter countless situations 
where they are expected to produce English texts using a far larger number of collocations that can be covered in class. Furthermore, it is virtually impossible for one language teacher to meet each individual learner's needs when there are dozens of students with various levels of proficiency from different majors. As Durrant (2009) pointed out, imparting knowledge of certain "important" collocations without taking sufficient account of variation across disciplines cannot possibly enable learners to write successfully in a comparatively advanced language proficiency. To quote the well-known maxim, language teachers need to teach students how "to fish" than give them "a fish." In other words, rather than confining to what collocations to teach, language teachers need to provide an autonomous learning tool that students can use in their endeavors to produce an English text.

Despite recognized significance of collocations for both accuracy and fluency (Nation and Webb 2011), a review of the relevant literature indicates that there are a limited number of studies conducted in EFL contexts that suggest ways to increase learners' collocational competence. To address this research gap, the present study was undertaken to examine the teachability of collocations through fostering collocation dictionary skills. More specifically, this investigation attempted to answer the following research questions:

(1) Does teaching collocation dictionary skills affect EFL learners' ability to produce collocations correctly?

(2) How do EFL learners perceive the learning of collocation dictionary skills?

\section{Literature review}

\subsection{Definition of collocation}

The term collocation has its origin in the Latin verb collocare, which means "to set in order/to arrange" (Martyńska 2004), and is used to refer to binary lexical combinations that "occur physically together or have stronger chances of being mentioned together" (Sinclair 1991: 170). In this regard, Gitsaki (1999) reviewed the three main approaches to collocations - lexical, semantic, and structural.

The lexical approach was first proposed by Firth (1957) and is based on the idea of word meaning at the lexical level. Lexical collocations comprise two or more content words as in noun + verb, verb + noun, adjective + noun, adverb + adjective, verb + adverb, and adverb + verb combinations. Following Firth (1957), Halliday et al. (1964) also explained collocation as the tendency of a lexical item to co-occur with one or more words.

Unlike the lexical approach, the semantic approach perceives the meaning of a lexical item as its semantic properties, which determine possible collocates (Cruse 1986). However, this approach is criticized for being unable to explain the large number of idiosyncratic co-occurrences that are arbitrarily restricted (Gitsaki 1999). 
While the lexical and semantic approaches focus only on lexical words, the structural approach takes both lexical and grammatical collocations into consideration (Benson et al. 2010). According to this approach, collocations are viewed as combinations of a content word and a preposition or a grammatical structure like an infinitive or a clause. The structural approach is considered more pedagogical than the lexical and semantic approaches.

According to Nesselhauf (2003), collocations are to be delimited from other types of word combinations - such as "free combinations" (Cowie 1994) and "idioms" - based on arbitrary restriction on substitutability criterion. In a $v e r b+$ noun combination (e.g., read a newspaper), for instance, if the senses of the verb and the noun are both unrestricted so that they can be freely combined with a number of other nouns and verbs (e.g., read a book/a letter/a sign/a manual/ a leaflet), it is regarded as a free combination. In the case of perform a task, on the other hand, while the sense of the noun is unrestricted, that of the verb is restricted and thus can be combined with certain nouns only from a semantic point of view (e.g., " perform a survey). Therefore, the combination perform a task is a collocation. Unlike the aforementioned cases, if both the verb and the noun are used in a restricted sense so that substitution is either not at all possible or extremely limited, such a combination is classified as an idiom (e.g., sugar/sweeten the pill).

\subsection{Second language (L2) learners' difficulty in collocation production}

The importance of collocational knowledge is beyond dispute. It enables learners to produce L2 texts that are more understandable and native-like (Hunston and Francis 2000). However, empirical studies have repeatedly reported learners' problems with L2 collocational use across proficiency levels (Biskup 1992).

Understandably, one of the biggest hindrance to the learning of collocations lies in the idiosyncratic nature of collocations (Halliday 1966). As depicted in Wray (2002: 73), "in English you run a business, but in German you lead it ... In English you smoke a cigarette, but in Hindi you drink it ... In English you lie in the sun, but in Russian you lie on it." Since neither syntactic nor semantic rules of English have been able to account for collocations, from the learner's perspective they appear to be co-occurrence of "seemingly inexplicable lexical choices" underlying so-called collocations (Bartsch 2004: 19).

Furthermore, the lack of exposure to the target language poses an equally serious problem. While native speakers acquire the knowledge of lexical constraints leading to the co-selection of particular words as they grow up in their speech community, most L2 learners who learn English almost exclusively within the classroom environment are deprived of such an opportunity. Devoid of linguistic intuitions and the ability to produce appropriate collocations (Groom 2009), they cannot but turn to their native language (L1) (Koya 2003, Laufer and Waldman 2011). According to the results of the previous studies, L2 learners often falsely assume a one-to-one correspondence between 
L1 and L2 collocational choices, unaware that different languages follow markedly different collocational rules. Consequently, unless the collocation in their L1 happens to match that in L2, negative transfer occurs, resulting in deviant L2 combinations (Bahns and Eldaw 1993, Ellis 2008, Gass and Selinker 2008).

\section{The study}

\subsection{Participants}

The participants were 59 EFL college students attending a large private university in Seoul, Republic of Korea. Before the start of the new school year, all incoming students took the school-organized English proficiency test and were assigned to take English courses according to their proficiency level. The participants were from two intact freshman English classes that the author taught: One $(n=30)$ was for basic to low-intermediate students (hereafter referred to as the "low-intermediate group"), and the other $(n=29)$ for intermediate to advanced students (hereafter referred to as the "advanced group"). The class met twice a week over the span of roughly 15 weeks, and each class lasted for 75 minutes.

The participants were 19-22 years old and had learned English both at elementary and secondary schools and private language institutions for an average of approximately 12 years when they enrolled in the course. English was a foreign language for all of them with no prior experience of living in an English-dominant country, except for two students who had lived in the US for four years and two and a half years, respectively. Regarding ethnicity, Koreans constituted $73 \%$, Chinese $24 \%$, and Japanese $3 \%$ of the participants. The students of Chinese and Japanese nationality were fluent enough in Korean to understand written Korean vocabulary used in the collocation production tests and the collocation instruction worksheets.

\subsection{Instruments}

\subsubsection{Pre-semester survey}

The participants took a pre-semester survey on the first day of the semester. The survey items were regarding personal data such as name, age, and experience living abroad; language learning history; and their familiarity with the term/concept "collocation."

\subsubsection{Collocation production tests}

The collocation production tests were administered before and after the experimental intervention at a 12-week interval (in Weeks 1 and 13). To see 
whether or not teaching collocation dictionary skills attributes to the development of learners' collocation production ability, the test scores were compared.

For a pilot study conducted before the start of the semester, 36 items were written concerning three collocation types $(v e r b+$ noun, adjective + noun, and preposition + noun combinations), with 12 items per each type. They were drawn from McCarthy and O'Dell (2005) and online resources with revisions. Nine students were recruited from the same study population that would be used for the subsequent study. They were asked to elicit without dictionary consultation a collocating verb for the first type, an adjective for the second, and a preposition for the third. When multiple answers were possible, they were required to give only one answer, and all the correct answers were awarded one point. For instance, for the blank in the item ..... (과중한) workloads are not uncommon in today's workplace, any one of the adjectives enormous, heavy, and huge was graded as correct.

Based on the result of the pilot study, the author sifted out six sentences (two from each type) that were found to be relatively easy and entailed no dictionary consultation. Then, the remaining 30 items were divided into two test sets of comparable difficulty (Type A and Type B), each consisting of 15 questions (see Appendix 1). For convenience of reference, each item number was followed by its test type (e.g., $3 \mathrm{~A}$ for the third question in the Type A test). In the main study, half of the participants, whose student ID ends with an odd number, took the Type A as a pre-test and the Type B as a post-test; and the other way around for the other half, whose student ID ends with an even number.

With an exception of test-taking situations, students engage in a writing task flexibly using resources according to their needs. Moreover, since the present study did not concern EFL learners' prior knowledge of the target collocations, the participants took the test in a computer lab, freely using the desktop computers or their smartphones as resource materials.

\subsubsection{End-of-semester survey}

The end-of-semester survey was administered on the last day of the semester. The participants responded to an open-ended survey question, which solicited comments on the instruction they received on collocation and collocation dictionary look-up skills. They were allowed to choose from either Korean or English when answering the question.

\subsection{Design for collocation dictionary skills instruction}

For two consecutive class sessions (Classes 1 and 2) in Week 5, the participants received instruction relevant to collocational competence development. During Class 1, they were taught "what collocation is" and "why it is important." For 
Class 2, the class met in the computer lab and received the 4-step instruction devised by the author, drawing upon Chen's (2016) observations on the causes of unsatisfactory collocation dictionary consultation behavior of L2 learners. After learning "how to check for collocational information" using the Naver Dictionary - the online dictionary service offered by Naver, one of Korea's major web portals - the participants worked on the collocation production task comprising a set of exercise questions in the formats of fill-in elicitation and sentence correction. Additionally, since the first drafts of their first writing assignment were returned that day, the students were asked to correct the marked (highlighted with a proofreading abbreviation "C" written on top) collocation errors - along with other lexical, grammatical, and discoursal aspects of their written work - and submit a revision by the next class meeting. The subsections below outline the four steps that the students were introduced to in Class 2 .

\subsubsection{Node word selection}

As a way to teach collocation dictionary skills, the instructor first explained the overall lexicographic presentation of the Naver Dictionary, which provides collocational information retrieved from the Oxford Collocations Dictionary for Students of English as a separate section entitled 함께 쓰이는 단어 (literally meaning "words used together") at the bottom of the look-up result page complemented by examples for the respective collocation types. Then, she demonstrated how to locate a list of feasible collocates using a "node word" - the term used to refer to an entry word to look up in the collocation dictionary (Sinclair 1991).

In addition, the students were instructed on how to divide a sentence into meaningful segments to pick a correct node word and how to simplify it if necessary. For instance, to fill in the blank in the sentence CEO of Apple Steve Jobs resigned ...... (때문에) health reasons and Tim Cook officially took over the reigns on August 24, 2011, the students were told to divide the sentence into four segments ([Segment 1] CEO of Apple Steve Jobs resigned [Segment 2] . . . . . (때문에) health reasons [Segment 3] and Tim Cook officially took over the reigns [Segment 4] on August 24, 2011) and use reason - not its plural form, reasons, nor the immediately adjacent resigned or health - as a node word, which directed them to the possible preposition collocate - for. In the same manner, for the gapped sentence While the names of some ingredients may sound exotic, many are ..... (손쉽게) available ..... . (에서) any local supermarket, the students were advised to use available as a node word for the first blank, and a simplified version of supermarket - market - for the second.

\subsubsection{Word sense distinction}

After learning how to choose a simplest possible node word for locating its collocate(s), the students were introduced to the layout of an entry for a polysemous word. Here, the instructor repeatedly urged the students to 
examine all the word senses, not just the first one or two (Chen 2016), until they run into the correct meaning in the given context. For example, after typing in the node word time to fill in the first blank in It was extremely difficult to . . . . . (정하다) a time for a make-up class ..... (에) weekdays, the students were directed to the result page showing nine definitions of time when used as a noun, along with its meaning as a verb (see Figure 1). In this case, the correct sense of the word is the third one ("time when sth happens/should happen").

\section{함께 사용되는 단어}

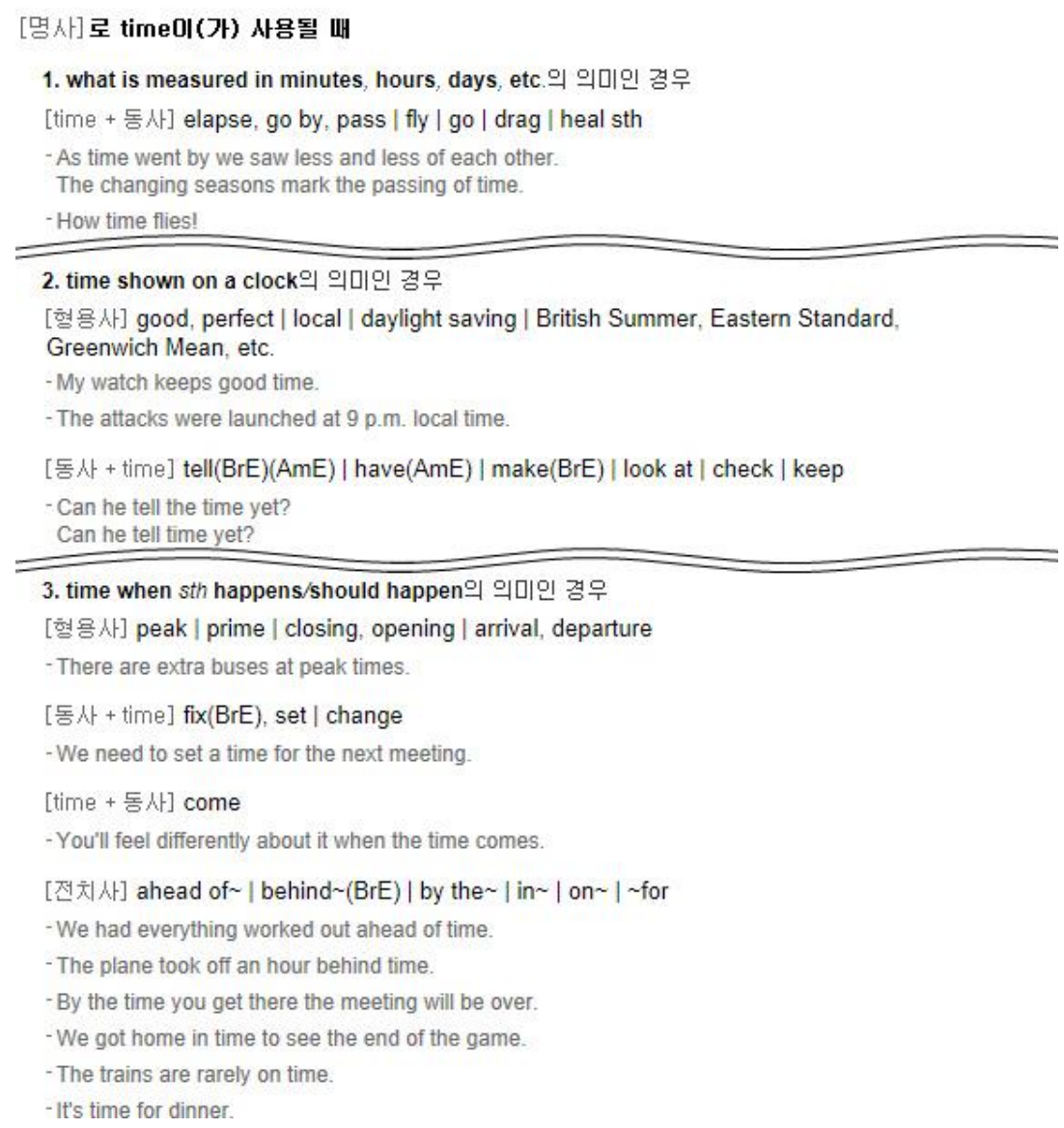

Figure 1: Screenshot of the Naver Dictionary for the entry word time, noun

\subsubsection{Collocate type location}

After identifying the correct sense of the multiple-meaning node word, the participants were asked to locate the collate type they were looking for. Since 
the Korean translation of the expected collocate was provided next to each blank, this step took almost no effort to complete and was finished immediately.

\subsubsection{Feasible collocate identification}

The last step for consulting collocational information was to identify the possible collocate(s) in the given context. For the gapped sentence College students should ..... (지다) responsibility for their own learning, for example, the students first typed in responsibility as a node word. Then, the result page showed a list of feasible collocates divided by vertical bars, denoting that those enumerated within the vertical bars can be used interchangeably (see Figure 2). In this case, the correct collocates are the second set of verbs (accept, acknowledge, assume, bear, shoulder, carry, recognize, shoulder, take, take on, take over).

\section{함께 사용되는 단어}

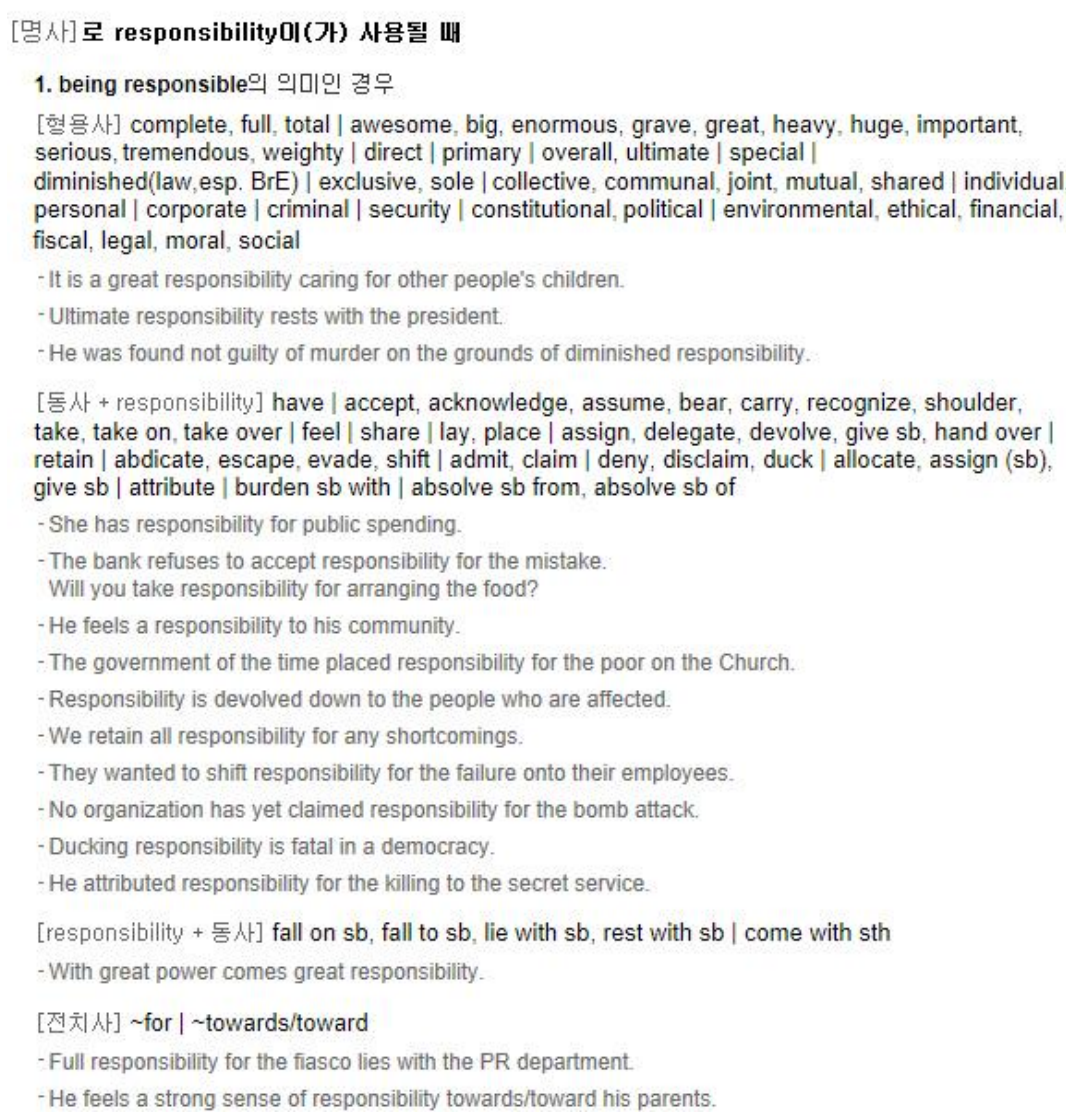

Figure 2: Screenshot of the Naver Dictionary for the entry word responsibility, noun 


\subsection{Data analysis}

Four sets of data were collected and analyzed: the yes/no answers to the presemester survey question about familiarity with the term/concept collocation, the pre-test collocation production task scores, the post-test collocation production task scores, and the comments to the end-of-semester survey question. For the first data set, the number of "yes" responses was counted and its percentage was calculated. To examine "whether or not teaching collocation dictionary skills affects EFL learners' ability to produce collocations correctly" (Research Question 1), the pre- and post-tests were scored manually by the author. One point was awarded for each correct answer, up to the maximum total of 15. Then, the participants' pre-test scores were compared against their post-test scores by a paired-samples $t$-test, using an alpha level of .05 . To probe into "how EFL learners perceive the learning of collocation dictionary skills" (Research Question 2), the end-of-semester survey data were analyzed. The comments obtained from the open-ended question were categorized; frequencies were counted and ranked.

\section{Results}

\subsection{EFL college students' familiarity with collocation}

The analysis of the pre-semester survey data indicated that collocation is a foreign concept to almost all participants. To the question "whether or not they have heard of the term 'collocation' before," 58 of 59 students responded "no." In Korean, collocation ("연어") and salmon ("연어") are homonyms. Although the survey item was written in both Korean and English, two respondents answered the question by asking in return, "Salmon as in salmon sushi?" Only one student answered that she had heard of it from her private English academy teacher. To the follow-up question "if and how she uses a collocation dictionary," however, the answer was negative. Confirming what has been reported unanimously in the literature, most EFL learners were found to "have no knowledge of collocation dictionaries or other potential resources" that they can use to address their collocation problems (Henriksen 2013: 42).

\subsection{Comparison of pre- and post-test scores}

To answer the first research question "whether teaching collocation dictionary skills affects EFL learners' ability to produce collocations correctly," a pairedsamples $t$-test was performed on each group's pre- and post-test composite scores. The descriptive statistics and statistical analyses are presented in Table 1. 
Table 1: Comparison of pre- and post-test composite scores

\begin{tabular}{lccccccc}
\hline \multirow{2}{*}{ Group } & \multirow{2}{*}{$N$} & \multicolumn{2}{c}{ Pre-test } & \multicolumn{2}{c}{ Post-test } & \multirow{2}{*}{$t$} & \multirow{2}{*}{$p$} \\
\cline { 3 - 6 } & & $M$ & $S D$ & $M$ & $S D$ & & \\
\hline Low-intermediate & 30 & 5.91 & 4.53 & 13.14 & 0.43 & -16.830 & .000 \\
\hline Advanced & 29 & 7.71 & 3.10 & 13.37 & 0.38 & -15.990 & .000 \\
\hline
\end{tabular}

The mean pre-test composite scores were 5.91 (out of 15) for the low-intermediate group and 7.71 for the advanced group. The mean post-test scores improved substantially to 13.14 and 13.37 for the low-intermediate and advanced groups, respectively. Not surprisingly, the $p$-values were reported far less than the significance level for both groups $(p=.000)$.

Then, to see if the instruction positively affects learners' collocation production ability without reference to collocation types, the paired-samples $t$-test was performed one more time on the three pre- and post-test subscale scores for the verb + noun, adjective + noun, and preposition + noun combinations. The results are shown in Table 2.

Table 2: Comparison of pre- and post-test subscale scores

\begin{tabular}{|c|c|c|c|c|c|c|c|}
\hline \multirow{2}{*}{ Group } & \multirow{2}{*}{ Collocation type } & \multicolumn{2}{|c|}{ Pre-test } & \multicolumn{2}{|c|}{ Post-test } & \multirow{2}{*}{$t$} & \multirow{2}{*}{$p$} \\
\hline & & $M$ & $S D$ & $M$ & $S D$ & & \\
\hline \multirow{3}{*}{$\begin{array}{l}\text { Low-interme- } \\
\text { diate }\end{array}$} & verb + noun & 2.44 & 1.17 & 5.00 & .00 & -12.227 & .000 \\
\hline & adjective + noun & 1.96 & .49 & 5.00 & .00 & -22.349 & .000 \\
\hline & preposition + noun & 1.51 & 1.79 & 3.14 & .43 & -5.662 & .000 \\
\hline \multirow[t]{3}{*}{ Advanced } & verb + noun & 3.00 & .44 & 5.00 & .00 & -15.874 & .000 \\
\hline & adjective + noun & 2.71 & 1.17 & 5.00 & .00 & -11.159 & .000 \\
\hline & preposition + noun & 2.00 & .59 & 3.37 & .38 & -7.258 & .000 \\
\hline
\end{tabular}

For the collocation type of the verb + noun combination, the mean subscale scores improved from 2.44 (out of 5) to 5.00 for the low-intermediate group and from 3.00 to 5.00 for the advanced group. For the collocation type of the adjective + noun combination as well, the participants achieved a considerable mean subscale score gain from 1.96 to 5.00 for the low-intermediate group and from 2.71 to 5.00 for the advanced group. As expected, the mean subscale score differences were statistically significant for both groups $(p=.000)$. For the collocation type of the preposition + noun combination, the mean subscale scores increased from 1.51 to 3.14 for the low-intermediate group and from 2.00 to 3.37 for the advanced group. Although the participants' performance on this type 
was not as impressive as on the first two collocation types, the mean subscale score gains were statistically meaningful for both groups $(p=.000)$.

\subsection{EFL learners' perception toward collocation dictionary skills instruc- tion}

To assess EFL learners' perception toward the learning of collocation dictionary skills, the answers to the open-ended survey question were analyzed. Since some participants offered multiple comments, the total number of responses is greater than the number of respondents. The comments written in Korean were translated into English by the author. Table 3 illustrates a summary.

Table 3: EFL learners' perception toward collocation dictionary skills instruction

\begin{tabular}{lc}
\hline \multicolumn{1}{c}{ Comment } & $\begin{array}{c}\text { Number of } \\
\text { responses }\end{array}$ \\
\hline $\begin{array}{l}\text { I feel confident about English writing now that I can check the natu- } \\
\text { ralness of a text by myself. }\end{array}$ & 37 \\
A collocation dictionary is a very useful tool for English composition. & 32 \\
$\begin{array}{l}\text { The way I consult a dictionary to look up natural-sounding colloca- } \\
\text { tions changed completely after receiving the instruction. }\end{array}$ & 16 \\
$\begin{array}{l}\text { Instruction on collocation dictionary skills should constitute an indis- } \\
\text { pensable part of English curriculum. }\end{array}$ & 11 \\
$\begin{array}{l}\text { There should be a bilingualised collocation dictionary to make it easier } \\
\text { to locate a correct sense of a polysemous word. }\end{array}$ & 6 \\
$\begin{array}{l}\text { A collocation dictionary should provide additional explanation, along } \\
\text { with a list of collocates, for collocations involving prepositions. }\end{array}$ & 4 \\
\begin{tabular}{l} 
Mobile collocation dictionary apps should be developed. \\
\hline
\end{tabular} & 1 \\
\hline
\end{tabular}

Overall, the respondents made favorable comments about the usefulness of the instruction targeting collocation dictionary skills development, and it was notable that none reported negatively about its helpfulness. A vast majority responded that the instruction helped them to gain or boost confidence with English writing, mainly thanks to increased collocational competence. Particularly, the participants valued the instruction, which - as one respondent put it "freed" them from having to ask others to proofread their "humble" papers, 
risking losing face. Such comments could be interpreted to mean that the instruction helps raise learner autonomy in collocation production. Over 23\% of the participants $(n=14)$ responded that their dictionary consultation behavior changed fundamentally after receiving the instruction. Specifically, they commented that they no longer check pages of examples in an English-Korean dictionary in search of similar-meaning sentences.

In addition to expressing opinions about the instruction, some respondents made suggestive feedback. Six students suggested that a bilingualised collocation dictionary should be made available because it was overly demanding to use the monolingual English collocation dictionary, especially when distinguishing senses for polysemous words and choosing a collocating preposition. As illustrated in Figures 1 and 2, the Naver Dictionary offers collocation information in English only, with the exception of the Korean phrases 이(가) 사용될 때 ("when used as sth") and 의 의미인 경우 ("in the case where it means sth") used repeatedly in the section, and the parts of speech in Korean e.g., 명사 ("noun"), 형용사 ("adjective"), 동사 ("verb"), and 전치사 ("preposition"). Also, one respondent addressed the need for developing a collocation dictionary app for the convenience of mobile-savvy college students.

\section{Discussion and conclusion}

The present study was an attempt to validate the effectiveness of the teaching of collocation dictionary skills in fostering EFL learners' collocational competence. In accordance with Laufer (2011) and Chen (2016), it was found that EFL learners - regardless of their proficiency level - significantly improved their ability to produce natural collocations with the aid of an online collocation dictionary. Also, the survey data suggested that the instruction targeting collocation dictionary skills development was positively perceived by the learners.

For the pre-test collocation production task, the overall correct answer rate was approximately $39 \%$ for the low-intermediate group and $51 \%$ for the advanced group. What was a little surprising was the unsatisfactory performance of the students in the advanced group, who were supposed to be relatively proficient in English. Besides, given that they could use a computer or a smartphone to consult online resources including dictionaries, the result that they managed to produce collocations only at a little over a $50 \%$ success rate was quite disappointing. In this regard, the result of the present study seems to lend further support to Howarth's $(1996,1998)$ and Nesselhauf's (2003) claim that collocations are challenging even to advanced-level learners, not to mention less proficient ones. Therefore, since a substantial number of word combinations that can be readily understood cause problems when producing them, it is deemed necessary for English instructors to raise learner's awareness of collocation (Chen 2016).

Interestingly, while proctoring the pre-test, the author/instructor could 
easily witness that a good many students did not bother consulting a dictionary or other online materials at their disposal. Instead, they at times filled in the blanks with deviant L2 collocates without hesitation, and did not check the correctness of their answers, possibly due to a lack of awareness that the collocations were in fact unfamiliar to them (Laufer 2011). Given that they produced collocations in such a manner during the collocation production test, it might go without saying that they do not consult dictionaries as often as they need to when they write. By and large, the observation seems to indicate that, consistent with Bahns (1993) and Bahns and Eldaw (1993), many EFL learners do not grasp the possible lexical incongruence between their L1 and the target language.

For Items 4A (All students are required to .... . . [듣다] at least two writing classes) and 6B (These are core courses you have to ..... . [듣다] this year), for instance, $46 \%$ of the students on average answered incorrectly and the wrong answers included hear, listen, and listen to, all of which are direct translation of the given Korean verb 듣다. Also, for Item 7A (You need a student ID card to ..... [연장하다] the library book), the inaccuracy level logged $75 \%$ among the students who took the Type A as a pre-test, and the two most frequent incorrect answers were extend and prolong - English equivalents for the given Korean verb 연장하다. As amply shown in previous studies, it was evident that learners across proficiency levels negatively transfer their linguistic knowledge of the L1 to an L2 context as a common learning strategy (Selinker 1992, Fan 2009, Sadeghi 2009).

Drawing a stark contrast with the performance on the pre-test, the analysis of the post-test scores provided a compelling evidence for the effectiveness of the instruction targeting collocation dictionary skills development. In accordance with Laufer (2011) and Chen (2016), teaching collocation dictionary skills significantly increased the number of correct collocations on the post-test. A close look into the participants' performance on each of the three collocation types showed that all participants got a perfect score for the verb + noun and adjective + noun combinations. Of course, the fact that the participants improved their collocations production ability comfortably conforms to the initial expectations of the study; however, such dramatic progress resulting in perfect performance was far beyond what any researcher could possibly expect. Even though further research is needed to identify possible factors, one plausible explanation might be that, since the test was to fill in the blank with a verb for the verb + noun combination and an adjective for the adjective + noun combination - both of which are "content" words - it must have been doable for the participants to sensibly distinguish among a number of feasible collocate sets. For Item 4B (It was so relaxing to be among . . . . . [0예전의] friends), for example, after typing in friend as a node word, one is directed to the result page presented in Figure 3.

Among a list of possible collocates, one can easily tell that the third set of adjectives - lifelong, long-standing, long-time, old - means the closest meaning 
to the provided Korean equivalent 예전의 ("old/past"). Therefore, once establishing a habit of consulting collocation dictionaries for collocational information, one may well find it easier to pick natural-sounding collocates for the node word than doing otherwise.

\section{함께 사용되는 단어}

\section{[몀사] 로 friend이(가) 사용될 때}

[혈용사] best, bosom, close, dear, fast(AmE), good, great, intimate, real, special | faithful, loyal, real, true, trusted | lifelong, long-standing(esp. BrE), long-time, old | long-lost | new, new-found | female, guy (AmE, informal), male, woman | gay, straight | single | fair-weather | so-called, supposed | mutual | family, personal | childhood, college, school | imaginary | online

- Her best friend at school was called Anna.

I'm inviting only my closest friends to the party.

- It was so relaxing to be among old friends.

- He was last seen leaving a restaurant with a female friend.

- Does your sister have any single friends?

- People he had trusted turned out to be only fair-weather friends.

- My so-called friends are making fun of me because of my weight.

- We met each other through a mutual friend.

-Do you keep in touch with any school friends?

Figure 3: Screenshot of the Naver Dictionary for the entry word friend, noun

For the preposition + noun collocation type, participants' post-test performance was not as impressive as on the other two collocation types, even though both groups achieved a statistically meaningful mean subscale score gains. Unlike Dziemianko's (2010) study, in which the Polish college students succeeded in completing gapped sentences with prepositions at an over $92 \%$ success rate, the average post-test score of the participants in this study was slightly over $65 \%$. Even though further investigations into this matter are required to establish the validity, it stands to reason that such a result was at least partly attributable to difference in word classes. That is, for this collocation type, the students were asked to fill in the blank with a preposition - a "function" word - which has little lexical meaning in its own nature (Fries 1952). In the case of Item 3A (Nowadays, we can buy Eiffel Tower tickets ..... [에서] the web), for example, after typing in web as a node word, one is directed to the result page that shows only one collocating preposition - on (see Figure 4).

\section{함께 사용되는 단어}

\section{[명사] 로 web이(가) 사용될 때}

1. that a spider makes의 의미인 경우

[혛용사] spider(esp. AmE), spider's(esp. BrE)

[동사 + web] build, make, spin, weave 
2. complicated series/network of $s t h$ 의 의미인 경우

[혛용사] complex, complicated, dense, intricate, tangled / seamless

[동사 + web] create, form, weave | be drawn into

- The mass media form a web of communications.

- More and more people were drawn into his web of deceit.

[Phrases] a $\sim$ of deceit, a $\sim$ of deception, a $\sim$ of intrigue, a $\sim$ of lies $\mid$ a $\sim$ of relationships

3. on the internet의 의미인 경우

[동사 + the Web] access | browse, search, surf | use

- Many people use the Web to make their travel plans.

[web + 명사] page | address, link | browser, server | resource, service | mail | network, ring | design, development | publishing | designer, developer, editor, host, master(usually webmaster), user | directory, guide, index | connection | access | search | content | application, tool

- a broadband Web connection

- A Web search brought up 9 hits.

[전치사] on the

- I found this survey on the Web.

Figure 4: Screenshot of the Naver Dictionary for the entry word web, noun

Expectedly enough, all participants filled in the blank with the correct preposition. Likewise, the items whose node words collocate with only one preposition (Items 3A, 12A, 2B, 5B, and 8B) also logged 100\% correct answer percentage. For those with multiple possible collocates (Items 5A, 9A, 15A, 11B, and 14B), however, the average accuracy percentage was only barely over $31 \%$. For Item 9A (The school provides free Wi-Fi .... . [에서] campus), for instance, after typing in the node word campus, one is directed to the result page presented in Figure 5.

\section{함께 사용되는 단어}

\section{[명사] 로 campus이(가) 사용될 때}

[혛용사] large, sprawling | small | main | college, school, university | corporate(AmE)

- The Engineering department is on the main campus.

[동사 + campus] have

- The university has campuses in Cairns and Brisbane

[campus + 명사] newspaper(esp. AmE) | bookstore(AmE) | novel(esp. BrE)

[전치사] at a/the | off | on

- Students at the Belfast campus have access to excellent sports facilities.

- The number of Harvard graduate students living off campus has dropped.

- She lives on campus.

Figure 5: Screenshot of the Naver Dictionary for the entry word campus, noun 
To fill in the blank, one needs to choose from the three options of at a/the , off $\sim$, and on $\sim$. The correct collocate is the last one as there is no article in front of campus in the given sentence. Despite the fact that it was heavily stressed during the instruction that they need to check whether or not a nominal node word is preceded by an article, a majority of the participants wrongly chose at. Since EFL learners tend to lack linguistic intuitions about naturalness of word combinations, it must have been challenging even for the advanced group to pick the correct collocating preposition. Similarly, for Item 14B (Her novel is ..... [에] the list of recommended readings), after typing in list as a node word, the participants must have been confronted with the choice between in and on (see Figure 6).

\section{함께 사용되는 단어}

\section{[몀사] 로 list이(가) 사용될 때}

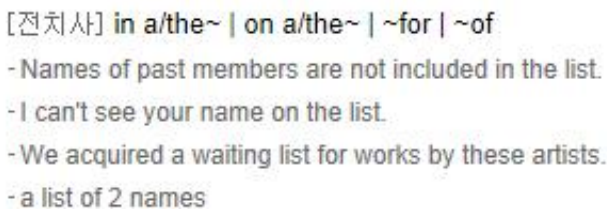

Figure 6: Screenshot of the Naver Dictionary for the entry word list, noun

Of course, one might have taken the hint from the example Names of past members are not included in the list that in the list, as opposed to on the list, is used after the verb include; but, honestly speaking, that sounds almost entirely unlikely. The fact that the accuracy percentage of the item recorded a scant $12 \%$ bears out the theory, suggesting that embedding additional information within an example is not salient enough to catch attention. Therefore, as suggested by Gouws (2015: 179), it seems necessary that collocation dictionaries provide "additional semantic guidance to ensure a successful comprehension of the collocation."

An equally significant, and encouraging, finding from this study is that the teaching of collocation dictionary skills changed the participants' dictionary consultation behavior. While proctoring the post-test, the author could easily observe the difference: The students navigated to the online collocation dictionary and then took on the collocation production task. As described earlier, quite many of them filled in the blanks on the pre-test without consulting a dictionary or other materials, which often led to inaccurate output. After receiving the instruction, however, the students began to check for collocational word parings in L2, which they used to take for granted if those word combinations made sense in their L1. Since they were provided with written feedback on collocation errors in their six writing assignment drafts throughout the semester and were encouraged to correct them by themselves with the help of a collocation dictionary, all participants must have become familiar with the collocation dictionary by the time they took the post-test. Given that colloca- 
tions cannot be possibly predicted, the fact that the students began to develop the habit of consulting collocation dictionaries - albeit not necessarily voluntarily - might be the single most meaningful outcome of this study.

All in all, the improvement the participants made in producing correct collocations after receiving two 75-minute instructions was dramatic, indeed. The attempt at teaching EFL students "how to fish" seems to have suitably equipped them with an autonomous learning tool with which they can take charge of their own learning, free from teacher guidance or direction (Woolard 2000, Smith 2008). In addition to the improved reference skills, the participants' newly formed habit to consult a dictionary for collocation decoding seems to equally contribute to the positive results of the current study. As Zimmerman (2009) pointed out, non-native students need to turn to collocation dictionaries to achieve accurate and fluent collocation production, and it is a language instructor's job to teach them the necessary skill to do so (Ranalli 2013).

\section{References}

Ackermann, K. and Y.H. Chen. 2013. Developing the Academic Collocation List (ACL): A CorpusDriven and Expert-judged Approach. Journal of English for Academic Purposes 12(4): 235-247.

Bahns, J. 1993. Lexical Collocations: A Contrastive View. ELT Journal 47(1): 56-63.

Bahns, J. and M. Eldaw. 1993. Should We Teach EFL Students Collocations? System 21(1): 101-114.

Bartsch, S. 2004. Structural and Functional Properties of Collocations in English: A Corpus Study of Lexical and Pragmatic Constraints on Lexical Co-occurrence. Tübingen: Gunter Narr.

Benson, M., E. Benson and R.F. Ilson (Eds.). 2010. The BBI Combinatory Dictionary of English: Your Guide to Collocations and Grammar. Third edition. Amsterdam: John Benjamins.

Biskup, D. 1992. L1 Influence on Learner's Renderings of English Collocations: A Polish/German Empirical Study. Arnaud, P.J.L. and H. Béjoint (Eds.). 1992. Vocabulary and Applied Linguistics: 85-93. London: Macmillan.

Chen, Y. 2016. Dictionary Use for Collocation Production and Retention: A CALL-Based Study. International Journal of Lexicography. doi:10.1093/ijl/ecw005.

Conzett, J. 2000. Integrating Collocation into a Reading and Writing Course. Lewis, M. (Ed.). 2000. Teaching Collocation: Further Developments in the Lexical Approach: 70-87. Hove, UK: Language Teaching.

Cowie, A.P. 1994. Phraseology. Asher, R.E. (Ed.). 1994. The Encyclopedia of Language and Linguistics: 3168-3171. Oxford: Pergamon.

Cowie, A.P. (Ed.). 1998. Phraseology: Theory, Analysis and Applications. Oxford: Clarendon Press.

Cruse, D.A. 1986. Lexical Semantics. Cambridge: Cambridge University Press.

Durrant, P. 2009. Investigating the Viability of a Collocation List for Students of English for Academic Purposes. English for Specific Purposes 28(3): 157-169.

Dziemianko, A. 2010. Paper or Electronic? The Role of Dictionary Form in Language Reception, Production and the Retention of Meaning and Collocations. International Journal of Lexicography 23(3): 257-273.

Ellis, R. 2008. The Study of Second Language Acquisition. Oxford: Oxford University Press.

Fan, M. 2009. An Exploratory Study of Collocational Use by ESL Students - A Task Based Approach. System 37(1): 110-123. 
Firth, J.R. 1957. Papers in Linguistics 1934-1951. London: Oxford University Press.

Fries, C.C. 1952. The Structure of English. New York: Harcourt Brace.

Gass, S.M. and L. Selinker. 2008. Second Language Acquisition: An Introductory Course. New York: Routledge.

Gitsaki, C. 1999. Second Language Acquisition: A Study of the Development of Collocational Knowledge. San Francisco: International Scholars.

Gouws, R.H. 2015. The Presentation and Treatment of Collocations as Secondary Guiding Elements in Dictionaries. Lexikos 25: 170-190.

Granger, S. 1998. Prefabricated Patterns in Advanced EFL Writing: Collocations and Formulae. Cowie, A.P. (Ed.). 1998. Phraseology: Theory, Analysis and Applications: 145-160. Oxford: Oxford University Press.

Granger, S. and F. Meunier (Eds.). 2008. Phraseology. An Interdisciplinary Perspective. Amsterdam/ Philadelphia: John Benjamins.

Groom, N. 2009. Effects of Second Language Immersion on Second Language Collocational Development. Barfield, A. and H. Gyllstad (Eds.). 2009. Researching Collocations in Another Language: Multiple Interpretations: 21-33. Basingstoke, UK: Palgrave Macmillan.

Halliday, M.A.K. 1966. Lexis as a Linguistic Level. Bazell, C.E., J.C. Catford, M.A.K. Halliday and R.H. Robins (Eds.). 1966. In Memory of J.R. Firth: 148-162. London: Longman.

Halliday, M.A.K., A. McIntosh and P. Strevens. 1964. The Linguistic Sciences and Language Teaching. London: Longmans.

Henriksen, B. 2013. Research on L2 Learners' Collocational Competence and Development - A Progress Report. Bardel, C., C. Lindqvist and B. Laufer (Eds.). 2013. L2 Vocabulary Acquisition, Knowledge and Use. New Perspectives on Assessment and Corpus Analysis. Eurosla Monographs Series 2: 29-56. European Second Language Association.

Howarth, P. 1996. Phraseology in English Academic Writing. Some Implications for Language Learning and Dictionary Making. Tübingen: Max Niemeyer.

Howarth, P. 1998. Phraseology and Second Language Proficiency. Applied Linguistics 19(1): 24-44.

Hunston, S. and G. Francis. 2000. Pattern Grammar: A Corpus-driven Approach to the Lexical Grammar of English. Amsterdam: John Benjamins.

Jiang, J. 2009. Designing Pedagogic Materials to Improve Awareness and Productive Use of L2 Collocations. Barfield, A. and H. Gyllstad (Eds.). 2009. Researching Collocations in Another Language: 99-113. New York: Palgrave Macmillan.

Kennedy, G.D. 1990. Collocations: Where Grammar and Vocabulary Teaching Meet. Anivan, S. (Ed.). 1990. Language Teaching Methodology for the Nineties: 215-219. Singapore: SEAMEO Regional Language Centre.

Koya, T. 2003. A Study of Collocation in English and Japanese Noun-Verb Combinations. Intercultural Communication Studies 12(1): 125-141.

Laufer, B. 2011. The Contribution of Dictionary Use to the Production and Retention of Collocations in a Second Language. International Journal of Lexicography 24(1): 29-49.

Laufer, B. and T. Waldman. 2011. Verb-Noun Collocations in Second Language Writing: A Corpus Analysis of Learners' English. Language Learning 61(2): 647-672.

Lewis, M. (Ed.). 2000. Teaching Collocations: Further Developments in the Lexical Approach. Hove, UK: Language Teaching Publications.

Martyńska, M. 2004. Do English Language Learners Know Collocations? Investigationes Linguisticae 11: $1-12$. 
McCarthy, M. and F. O'Dell. 2005. English Collocations in Use. Cambridge: Cambridge University Press.

Nation, P. and S.A. Webb. 2011. Researching and Analyzing Vocabulary. Boston: Heinle Cengage Learning.

Nattinger, J.R. and J.S. DeCarrico. 1992. Lexical Phrases and Language Teaching. Oxford: Oxford University Press.

Nesselhauf, N. 2003. The Use of Collocations by Advanced Learners of English and Some Implications for Teaching. Applied Linguistics 24(2): 223-242.

Nesselhauf, N. 2005. Collocations in a Learner Corpus. Amsterdam/Philadelphia: John Benjamins.

Ranalli, J. 2013. Designing Online Strategy Instruction for Integrated Vocabulary Depth of Knowledge and Web-based Dictionary Skills. CALICO Journal 30(1): 16-43.

Sadeghi, K. 2009. Collocational Differences Between L1 and L2: Implications for EFL Learners and Teachers. TESL Canada Journal 26(2): 100-124.

Selinker, L. 1992. Rediscovering Interlanguage. London: Longman.

Sinclair, J. 1991. Corpus, Concordance, Collocation. Oxford: Oxford University Press.

Smith, R. 2008. Learner Autonomy. ELT Journal 62(4): 395-397.

Wible, D., C-H. Kuo, M-C. Chen, N-L. Tsao and T-F. Hung. June 2006. A Computational Approach to the Discovery and Representation of Lexical Chunks. Proceedings of the 13th Conference on Natural Language Processing (TALN 2006), 10-13 April, 2006, Leuven, Belgium: 868-875.

Woolard, G. 2000. Collocation: Encouraging Learner Independence. Lewis, M. (Ed.). 2000. Teaching Collocation: Further Developments in the Lexical Approach: 28-46. Hove, UK: Language Teaching Publications.

Wray, A. 2002. Formulaic Language and the Lexicon. Cambridge: Cambridge University Press.

Ying, Y. and M. O'Neill. 2009. Collocation Learning Through an 'AWARE' Approach: Learner Perspectives and Learning Process. Barfield, A. and H. Gyllstad (Eds.). 2009. Researching Collocations in Another Language: 181-193. New York: Palgrave Macmillan.

Zimmerman, C.B. 2009. Word Knowledge: A Vocabulary Teacher's Handbook. Oxford: Oxford University Press. 
Appendix 1: Collocation production tests

\section{Type A}

Fill in the blank with the most appropriate word.

1A. An unbalanced diet can ..... (야기하다) serious problems.

2A. ...... (과중한) workloads are not uncommon in today's workplace.

3A. Nowadays, we can buy Eiffel Tower tickets ..... (에서) the web.

4A. All students are required to ..... (듣다) at least two writing classes.

5A. She was filled with many emotions ..... (에) her 20th birthday.

6A. Students drink energy drinks or ..... (진한) coffee to stay up late.

7A. You need a student ID card to ..... (연장하다) the library book.

8A. The school cafeteria has a(n) ..... (다양한) menu for lunch.

9A. The school provides free Wi-Fi ..... (에서) campus.

10A. With this timeline, we can ..... (맞추다) the schedule.

11A. There will be ..... (많은) snow tomorrow.

(Note: Do not use "a lot of" or "lots of" to fill in the blank.)

12A. There are many historic buildings ..... (에는) this university.

13A. Teachers often ..... (내다) assignments far beyond students' abilities.

14A. There was a(n) ..... (강한) smell of burning tires.

15A. Students can check almost all information ..... (에서) the Internet.

\section{Type B}

Fill in the blank with the most appropriate word.

1B. The shop offers a(n) ..... (다양한) selection of wines.

2B. I am going to a concert ..... (에) Christmas Eve.

3B. Many countries ..... (입다) damage every year from the typhoon.

4B. It was so relaxing to be among ..... (예전의) friends.

5B. We can easily find free online chatting sites ..... (에서) the website.

6B. These are core courses you have to ..... (듣다) this year.

7B. I like the .... (진한) scent of Indian cooking.

8B. I think I did badly ...... (에서) the history test.

9B. We must ..... (하다) an effort to stay healthy.

10B. Below are some of the most ..... (흔한) English mistakes. 
11B. The event was canceled ..... (때문에) safety reasons.

12B. You can ..... (채우다) three credits by taking this course.

13B. Many health problems are associated with ..... (과도한) drinking.

14B. Her novel is ..... (에) the list of recommended readings.

15B. Most journalists work under pressure to ..... (맞추다) deadlines. 